\title{
THE FEELING OF RELIGIOUS LONGING AND PASSIONATE RATIONALITY
}

\author{
RUTH REBECCA TIETJEN
}

University of Tübingen

\begin{abstract}
What is the feeling of religious longing and how, if at all, can religious longing justify religious beliefs? Starting with an analogy between religious longing and basic physical needs and an analogy between religious longing and musical longing, I argue that the feeling of religious longing is characterized by four features: (1) its generality, (2) its indeterminate transcendent object which by its nature is not capable of empirical verification or falsification, (3) its mode of being infinitely interested in passion and (4) its ambiguity with regard to our own power and powerlessness. Religious longing can neither epistemically nor pragmatically justify religious beliefs. If we want to account for the rationality of religious beliefs motivated by religious longing, we have to consider passionate rationality as a third kind of rationality. We wholeheartedly take as true what we experience as a condition of the possibility of (an understandable, meaningful) life.
\end{abstract}

Apostle Paul writes in his letter to the Romans:

For I consider that the sufferings of this present time are not worthy to be compared with the glory that is to be revealed to us. For the anxious longing of the creation waits eagerly for the revealing of the sons of God. For the creation was subjected to futility, not willingly, but because of Him who subjected it, in hope that the creation itself also will be set free from its slavery to corruption into the freedom of the glory of the children of God. For we know that the whole creation groans and suffers the pains of childbirth together until now. And not only this, but also we ourselves, having the first fruits of the Spirit, even we ourselves groan within ourselves, waiting eagerly for our adoption as sons, the redemption of our body. For in hope we have been saved, but hope that is 
seen is not hope; for who hopes for what he already sees? But if we hope for what we do not see, with perseverance we wait eagerly for it. In the same way the Spirit also helps our weakness; for we do not know how to pray as we should, but the Spirit Himself intercedes for us with groanings too deep for words; and He who searches the hearts knows what the mind of the Spirit is, because He intercedes for the saints according to the will of God. ${ }^{1}$

In this passage, Apostle Paul describes a state of longing in which we shall find ourselves; a state of anxious longing and eagerly waiting. $\mathrm{He}$ describes it as a state in which not only we as people shall find ourselves, but together with us the whole of creation. In the state of faith, this feeling of longing is at the same time a state of belief. 'What kind of state is this anxious longing?', we ask ourselves; we, who do not groan (or at most about our work); we, who believe ourselves not to be anxious (or at least not in this way) and not to hope for the kingdom of God; we, who do not hear the groaning of nature, but at most its indifferent silence.

The state described here is obviously a kind of feeling (understood in a broad sense). It is a feeling which on the one hand is directed to our present state, and on the other hand points beyond this present state. We experience our current state as painful, and, at the same time, anticipate the possibility of release from our pain. We experience that what we could be is not exhausted by what we are. This possible state of being that we anticipate is not a neutral possibility, but the object of our longing and hope, and our anticipation is not a cognitive state additional to our feeling, but itself part of it. The painful state in which we are is not simply a state in which we find ourselves through no fault of our own; it is a state for which we partly bear responsibility. But at the same time, and this is crucial for the feeling of religious longing, we experience this state as something from which we cannot free ourselves without help from the outside. What we are longing for is partly beyond our own power, so our feeling of longing is at the same time a feeling of being dependent on something other than ourselves.

For an illustration of this phenomenon, consider the mundane example of experiencing oneself as falling short of one's own potential. I often sit at my desk and want to work, but am unable to concentrate. When this state lasts the whole day, I feel frustrated in the evening because I have not achieved what I wanted to achieve, should have

${ }^{1}$ New American Standard Bible, Rom. 8:18-27. 
achieved and, most importantly, could have achieved. But what was the reason for my failure? It was my lack of concentration. I blame myself for it. 'If only I had concentrated', I think. At the same time I know that my ability to concentrate on my work is not completely in my own hands. Of course, I can go to sleep early, exercise and keep distractions out of my way. But this does not give me a guarantee. So, I can do nothing further than adjust the conditions of my work in a manner which is likely to enable my concentration, and, in addition to this, hope for the next day. If my hope is fulfilled and I even get into a flow of work, I feel much better in the evening due to what I achieved that day. But still, this feeling is accompanied by a vague sense of gratitude for the fact that my thinking went better that day. In other words, I have the experience that the conditions of my own mental productivity, the exhaustion of my intellectual potential, do not entirely lie in my own hands.

Let us now return to the religious sphere, in which infinitely more is at stake than our professional success or our philosophical productivity. As a preliminary result, we can conclude that the state of religious longing described by Paul points us toward a potential which lies in ourselves as well as in the Creation, but is not exhausted. We experience the exhaustion of this potential as something which lies partly within and partly beyond our own power. ${ }^{2}$

Paul describes the state of longing from the perspective of someone who is already in the state of faith. In the state of faith, our longing is not merely longing, but at the same time confidence. The believer dares to believe that what he is longing for is or will become real. But the feeling of religious longing can also be the starting point of faith. In this case, our longing is transformed into the belief that what we are longing for will be, and to some extent already is, real. This, at first sight, is an outrageous idea: to believe certain facts to be true, because one desires these facts to be true, is wishful thinking, and therefore, according to common opinion, the epitome of irrationality. According to this common point of view, the desire present in the feeling of religious longing might indeed be capable of motivating, but never of justifying religious belief.

The aim of my essay is to vindicate the transition from religious longing to religious belief as an instance of 'passionate rationality'.

${ }^{2}$ Interestingly, not only the fulfilment of our longing but also our experience of longing itself may be regarded as an ambiguous phenomenon. It is partly responsive and we are partly responsible for it. 
For this purpose, we should first characterize the feeling of religious longing. In the first paragraph I approach the feeling of religious longing via two analogies. This approach is founded on the fact that I - contrary to Paul - do not only focus on religious longing felt by people who are not (yet) in a state of faith, but also explore it from the perspective of someone who does not know the feeling (or at least believes herself not to know it) from her own experience. The first analogy compares religious longing with a physical need. It is prominently developed by Søren A. Kierkegaard and has recently been employed by Robert C. Roberts. The second analogy compares religious longing with the feeling of musical longing. In the current debate, Mark Wynn makes use of this analogy. In the second paragraph, I abstract a general characterization of the phenomenon of religious longing from these two analogies. I thereby assume the plausibility of the two analogies. Out of this characterization I extract the concept of religious feeling which must be assumed if religious longing is to be understood as a religious feeling, that is, firstly, as a feeling and, secondly, as religious. I thereby take for granted that religious longing is to be understood as a religious feeling. Based on this analysis, I finally turn to the transition from religious longing to religious belief. I argue that the contemporary debate about the justifying force of emotions does not help us to vindicate the epistemic or pragmatic rationality of this transition. But the phenomenon of religious belief motivated by religious longing opens up a new perspective on the role of feelings in the context of rationality. This perspective is captured in the concept of passionate rationality.

\section{TWO ANALOGIES}

What is religious longing felt by someone who is not (yet) in a state of faith and therefore does not have religious beliefs? We start with two analogies:

First analogy: Our religious longing is comparable to a basic physical need. A basic physical need is a need whose fulfilment is crucial for our physical well-being and flourishing. The concept of a basic need is therefore a genuine normative concept. According to the analogy, the relationship with God is a spiritual need, which manifests itself in spiritual illness if it remains unfulfilled, in the same way as unfulfilled physical needs express themselves in physical illness. This analogy is 
prominently developed by Søren A. Kierkegaard in 'The Sickness Unto Death', published under the pseudonym Anti-Climacus. ${ }^{3}$ According to Anti-Climacus, the sickness unto death is the spiritual illness which occurs if a person lacks a relationship (or the right kind of relationship) with God, if his relationship with God and therefore with himself, or conversely, his relationship with himself and therefore with God, is disturbed. Just like physical illness, mental illness occurs in degrees, depending on the degree to which our need is unfulfilled. At one end of the scale is death. The spiritual illness is a sickness unto death not because it finally leads to physical death, but because it leads to spiritual death, a death we suffer while alive and which for precisely that reason is so painful. The sickness unto death is despair and this is, in its most extreme variant, hopelessness. We lack any hope for salvation, so we feel something like an unsatisfiable desire; we feel that what we long for will, and must, remain forever out of our reach; we feel that there indeed is nothing more than our painful current state. Or perhaps we should rather say it is the state in which even our feeling of longing has become silent. At the other end of the scale is faith. As faith is not merely a state, but also an act, we cannot simply rest in a state of faith, but have to perform it. Just like faith, despair has a responsive as well as an active dimension.

Anti-Climacus' approach consists of three steps: the starting point is a description of the phenomenon of despair. In the second step, this phenomenon of despair is interpreted as a deficiency. In the last step, the conditions of mental health are extracted from this deficiency. Michael Theunissen has coined the concept of methodological negativism for this approach: the starting point is not an assumed normative standard of spiritual health, on the basis of which sickness is judged as an anomaly. On the contrary, the conditions of spiritual flourishing are inferred ex negativo from its failure. ${ }^{4}$ In particular, faith is defined 'only through the analysis of its negation. ${ }^{5}$

An analogous three-step development translated into practical terms can be found in the lives of those who encounter religious faith through the feeling of religious longing. William James describes developments of this kind in his lectures 'The Diversity of Religious Experience'. He gives a prominent role to Leo Tolstoy, who describes his own spiritual

\footnotetext{
${ }^{3}$ See Kierkegaard (1980).

4 See Theunissen (1981: 487).

5 Theunissen (1981: 489).
} 
development in his autobiographical report 'A Confession.' Tolstoy grew up in an Orthodox Christian home and environment, but apostasy from faith took place quickly. The pursuit of physical, mental and moral perfection is replaced by the pursuit of becoming richer, more famous and more important than others. He succeeds in achieving these aims and lives a successful life as an author. Like his colleagues, he believes in progress and, above all, in contributing to this progress by being a writer and therefore a teacher of mankind. But he becomes more and more aware that he himself does not know what to teach and which kind of life to live. The moments of doubt become more and more frequent and culminate in a serious crisis of life:

At first I experienced moments of perplexity and arrest of life, as though I did not know what to do or how to live; and I felt lost and became dejected. But this passed and I went on living as before. Then these moments of perplexity began to recur oftener and oftener, and always in the same form. They were always expressed by the questions: What is it for? What does it lead to?

This is the first step: the despair has a purely negative character. It expresses itself in the feeling of senselessness, and maybe also in the feelings of anxiety, nausea or boredom. In the second step, a feeling of religious longing emerges, a search for something, a vague hope for help:

During that whole year, when I was asking myself almost every moment whether I should not end matters with a noose or a bullet - all that time, together with the course of thought and observation about which I have spoken, my heart was oppressed with a painful feeling, which I can only describe as a search for God.

I say that that search for God was not reasoning, but a feeling, because that search proceeded not from the course of my thoughts - it was even directly contrary to them - but proceeded from the heart. It was a feeling of fear, orphanage, isolation in a strange land, and a hope of help from someone. ${ }^{8}$

In the more advanced form of this stage, Tolstoy's suffering is interrupted by brief moments of joy, in which he dares to believe and trust in God. In the next moment, however, he calls into question his own confidence,

\footnotetext{
${ }^{6}$ See James (2002), esp. lectures VI-VIII, Tolstoy (1940).

7 Tolstoy (1940: 15).

8 Tolstoy (1940: 62).
} 
destroys it through his reason and again is gripped by despair. Not until the third step is the final transition or leap from the feeling of longing to the state of religious faith performed:

But then I turned my gaze upon myself, on what went on within me, and I remembered all those cessations of life and reanimations that recurred within me hundreds of times. I remembered that I only lived at those times when I believed in God. As it was before, so it was now; I need only be aware of God to live; I need only forget Him, or disbelieve Him, and I died.

What is this animation and dying? I do not live when I lose belief in the existence of God. I should long ago have killed myself had I not had a dim hope of finding Him. I live, really live, only when I feel Him and seek Him. 'What more do you seek?' exclaimed a voice within me. 'This is He. He is that without which one cannot live. To know God and to live is one and the same thing. God is life.'

'Live seeking God, and then you will not live without God.' And more than ever before, all within me and around me lit up, and the light did not again abandon me. ${ }^{9}$

Second analogy: our religious longing is analogous to our musical longing for the harmonious resolution of a chord. We hear a dominant seventh chord and expect its resolution in the tonic; we hear a sequence of chords and expect that this sequence will be resolved harmoniously; we feel the rise of tension and expect that this tension will be dissolved. This 'expectation' is not a cognitive state, which is added on to our perception of the chord, or of the sequence of chords or of the tension. Rather, we already transcend the tension in the moment of perception. The 'anxious longing of the creature' about which Paul speaks or the 'veil of melancholy' which according to Schelling 'is spread over the whole of nature ${ }^{10}$ can therefore be compared to a musical tension which is waiting for its resolution. Just as the state of musical tension points at a state of musical resolution, our feeling of religious longing points at a state of resolution of this longing. 


\section{THE FEELING OF RELIGIOUS LONGING}

Which picture of religious longing emerges out of these two analogies? Which conception of religious feelings has to be assumed if religious longing is to be understood as a religious feeling, thus, firstly, as a feeling and, secondly, as religious? In the following, I abstract five features of religious longing from the two analogies introduced in the first paragraph. I hereby take the plausibility of the two analogies for granted. I neither aim at overruling all possible objections to the analogies, nor at defending against the alternative strategy of abandoning the analogies altogether.

First: different people may need different amounts of food, and there may be differences in the length of time before hunger asserts itself if one does not get any food. However, at some point, a feeling of hunger emerges. In the course of time, this feeling becomes more and more intense and gnawing and finally affects our physical and mental abilities. In the case of the alleged need for a relationship with God, things seem to be different: there are people who neither understand themselves as believers nor as unhappy. Their basic need for a relationship with God does not seem to be satisfied, but still they do not feel any religious longing. How can we account for this phenomenon, if we want to adhere to the idea that religious longing is the expression of a basic human need?

If we take the need for food as our paradigm, basic needs seem to have two characteristics: firstly, if a basic need is unfulfilled, it expresses itself as a feeling which is specific to the need in question. Secondly, the person having the feeling is conscious of his own feeling. The first strategy to take account of the described phenomenon is to give up the first condition. The lack of a relationship with God therefore does not necessarily express itself in a feeling. The absence of the feeling corresponding to the need is interpreted as a sign of spiritual immaturity. ${ }^{11}$ This case is comparable to the lack of sexual desire in children, which is regarded as a sign of their physical immaturity. We can also compare the lack of a feeling of religious longing to the case of someone who does not feel a need for education because he grew up in circumstances which did not allow him to develop such a need. So, though at first it seems one should give up the claim that something is a basic need rather than alleging this need despite many people not being aware of having such a need, on a second look adherents of a basic need theory of religious longing can in fact

\footnotetext{
${ }^{11}$ Cf. Roberts (2007: 36).
} 
refer to various other cases in which we proceed analogously without raising concerns of an analogous kind.

The second strategy consists in giving up the second condition. According to this approach, religious longing is a feeling which the person who feels it is not necessarily conscious of. This may mean either that the one who feels it is not reflectively conscious of his own feeling or that he is mistaken about the nature or content of his feeling. ${ }^{12}$ In both cases we usually take it to be necessary, first, that we can at least potentially become reflectively conscious of our own feeling, and second, that from the external perspective we cannot only give good reasons for assuming the presence of the feeling but also for the lack of (reflective) consciousness of it. Roberts pursues a mixed strategy. On the one hand, he argues that 'the natural need for God may be contingent on maturation. ${ }^{13}$ On the other hand he states that not 'each of us can, upon consulting the contents of our minds, find in ourselves a desire to praise God, or an emotion of despair that is obviously a frustrated state of our God-libido. Even if we are aware of wanting something that is not among the objects of our finite life, we may not know that we want God. ${ }^{14}$ Both strategies adhere to the view that a basic need is a need whose fulfilment is crucial for our flourishing.

The feeling of musical longing is also a feeling which people experience in various degrees. The degree to which we feel musical longing depends, among other factors, on our musical socialization, that is, our familiarity with the specific piece of music as well as with the particular musical tradition, and on our musical aptitudes. Just as there are unmusical people, the lack of religious longing and therefore of other religious feelings might be an expression of 'religious unmusicality'. This expression goes back to a letter of Max Weber's, who characterizes himself as 'absolutely unmusical in religious matters. ${ }^{15}$ He states that he neither has 'the need nor the ability to erect any religious edifies' in himself and characterizes his own lack of religious musicality as a form of 'crippledness'. Religious

${ }^{12}$ For the distinction between reflective and unreflective consciousness, cf. Goldie (2000: 62ff.).

${ }^{13}$ Roberts (2007: 36).

${ }^{14}$ Roberts (2007: 35f.).

15 Weber (1994: 65). The concept of religious unmusicality has been prominently picked up by Jürgen Habermas in his speech 'Faith and Knowledge'. Cf. Habermas (2001: 30). The idea is already expressed by Schleiermacher in his speeches 'On Religion'. Cf. Schleiermacher (2001: 134). 
musicality is therefore not simply described as an ability that one can have or lack, but as an ability which is part of human nature. Though we can conceive of a translation of the feeling of musical tension into the purely theoretical terms of music theory, we have the intuition that in this process of translation something important would be lost. This intuition is captured by contemporary emotion theories which hold emotions to be an indispensable way of understanding. ${ }^{16}$

Thus, the absence of a conscious feeling of religious longing does not necessarily indicate that the need for a relationship with God is not a basic need. It can also be interpreted as an expression of spiritual immaturity or as a sign of a lack or failure of reflective consciousness of one's own feeling.

Second: religious longing was introduced as a state in which we experience our present state as painful. But the analogy to musical longing suggests that the feeling of longing can also be enjoyed. Good music does not simply instantly fulfil all our longings, but rather plays with them. ${ }^{17}$ Other kinds of longing have similar characteristics, for example the feeling of being in love with someone. This feeling also involves an experience of both tension and longing for fulfilment. You feel this incredible attraction between yourself and someone else. When you look at each other your eyes rest on each other for just one moment too long. If they do not, it is not because the tension vanished, but because you resist your longing. Touches which in other contexts would be experienced as random or merely friendly create a tension which almost threatens to tear you apart. Although the feeling of tension in this case is also experienced as something aiming at resolution, it is not simply experienced as something to be overcome, but itself as something we take pleasure in. Exactly herein consists the attraction of prolonging the state of being in love as we do in the game of flirting. We can change between approach and withdrawal so often that the feeling of tension becomes nearly unbearable. This is only possible if the difference and distance between oneself and the other is maintained.

So, is it possible to analogously enjoy one's religious longing? In his pseudonymous work 'Either/Or', Kierkegaard describes exactly this phenomenon. The pleasure the aesthete A takes in his own despair is expressed in his aphorisms:

${ }^{16}$ E.g. cf. Goldie (2000: 59-62, 72-83); Wynn (2005: 98-102).

17 See Madell (1996: 75). 
In addition to my other numerous acquaintances, I have one more intimate confidant - my depression. In the midst of my joy, in the midst of my work, he beckons to me, calls me aside, even though physically I remain on the spot. My depression is the most trustful mistress I have known - no wonder, then, that I return the love.

I say of my sorrow what the Englishman says of his house: My sorrow is my castle. Many people look upon having sorrow as one of life's conveniences. ${ }^{18}$

Thus, the aesthete A takes pleasure in his own desperate existence and Johannes, the seducer, exhausts the pleasure of erotic tension by not primarily enjoying the fulfilment of his longing, but rather the possibility of its fulfilment and his own aesthetic play with this possibility.

Taking the plausibility of the analogies as a given, our analysis therefore leads to a second result: the painful state of religious longing can at least partly be experienced as pleasurable. We therefore have to admit that we cannot only be mistaken about our own state and its specific content, but also about its quality. At the same time it is important to be aware that taking pleasure in one's own longing always means maintaining a gap between oneself and one's longing.

Third: the feeling of religious longing has been described as a feeling that both represents the current state as deficient and points to our deliverance from suffering. So religious longing seems to be an intentional feeling. Currently, theories of emotions are a prominent kind of intentionality-focussed theories of feelings. In these theories, emotions are taken to be affective states which are directed towards a particular object. The emotion represents this object in a certain way. Either the intentional mode or the intentional content of the emotion is taken to involve an emotion-specific evaluation. Variants of these theories include judgement theories, perceptual theories and attitudinal theories of emotions. But religious longing is directed neither towards a particular object within the world, nor beyond the world. Rather, we feel that something is wrong with the life we are living or the world in which we find ourselves. What is wrong is not simply that this or that desire we have is unfulfilled. Something is wrong with our life in general, with our understanding and our project of life. So, what we learn is that what we usually take for granted - our conception of life and our basic interests, concerns, and ideas about what is valuable and worth striving

${ }^{18}$ Kierkegaard (1987: 20, 21). 
for - is not right and cannot satisfy us. The generality of the object of religious longing is also mirrored by the fact that religious longing can grip us anywhere and anytime. Though certain circumstances like a deadly disease or the death of a loved one can stimulate the feeling of religious longing, it is not tied to any particular situation, because it concerns the way we find ourselves in the world.

Analogously, the object of religious longing is indeterminate. We are longing for something but this something does not have a specific content. So, the feeling of religious longing is more like hearing the Tristan chord than hearing a dominant seventh chord: we feel that but not how the Tristan chord is to be resolved. We feel repulsed by our current being and at the same time attracted by what there might be beyond this current being. Religious longing is characterized by the fact that it cannot be fulfilled within our finite life. What we are longing for is something that transcends ourselves and the sensual world; we long for taking part in this something and for having a relationship with it. Thus, the object of our longing is, in the first place, determined in a purely negative manner; it is a 'border concept'.

Philosophical as well as religious traditions give us important insights into how we can specify the content of religious longing. We can distinguish between the quest for an ultimate explanation and the quest for an ultimate good. Both of these questions are questions which, according to Kant, human reason 'cannot decline, as they are presented by its own nature, but which it cannot answer, as they transcend every faculty of the mind. ${ }^{19}$ Kant calls these questions 'needs of reason' and therefore places them in the domain of reason, though, remarkably, at the same time he classifies them as needs. Furthermore, we can distinguish between monotheistic and pantheistic traditions, which give the transcendent the shape of a counterpart (God) or of an encompassing structure (the Divine), respectively. The transcendent is the placeholder which guarantees what we are longing for. The Christian God, for example, answers our quest for an ultimate explanation as well as our quest for an ultimate good. Roberts, who argues from the point of view of Christian tradition, further characterizes our religious longing by naming three aspects it involves: the need for something completely trustworthy, the need to be loved unconditionally and the need for an absolute meaning. ${ }^{20}$

${ }^{19}$ Kant (1987: A VII). 
We can conclude that religious longing is an intentional feeling not directed towards a particular object, but towards the way we find ourselves in the world. What we are longing for is something beyond the reach of our senses as well as of our reason. It is something transcendent whose form and content in the first place remains undetermined. Actually, says Paul, we know not what we should pray for, and we do not know how to pray. But he who searches the heart knows what the mind of the spirit is directed to.

Fourth: the comparison of religious longing with a basic need suggests that religious longing is a striving rather than an emotion. Accordingly, Roberts does not conceptualize religious longing as an emotion, but as a passion. Emotions are, according to him, concern-based construals. ${ }^{21}$ Religious longing is not a construal, but a concern of a specific kind, a passion:

A passion is a concern that can give a person's life a center, can integrate and focus the personality and give a person 'character'. A passion then is a kind of concern, but not every concern is a passion. [...] I use it [the word 'passion'] to refer neither to emotions nor to a general spiritedness of personality, but to a person's long-term, characteristic interests, concerns and preoccupations. [...] A passion in this sense is a concern that defines one's psychological identity. ${ }^{22}$

Likewise, Madell characterizes the feeling of musical longing as a desire:

As I have already claimed, music expresses emotion when it evokes emotion in such a way that the listener comes to identify with the course of the music, hears it from the inside, or has a first-person perspective on it. What leads to identification is the evocation of certain desires: the desire for the resolution of the discord, for example, or the desire that the pleasurable experience occasioned by its resolution may continue..$^{23}$

\footnotetext{
${ }^{20}$ See Roberts (2007: 37).

${ }^{21}$ See Roberts (2003).
}

${ }^{22}$ Roberts (2007: 17). Cf. Tillich (1957: 1): 'Faith is the state of being ultimately concerned: the dynamics of faith are the dynamics of man's ultimate concern. Man, like every living being, is concerned about many things, above all about those which condition his very existence, such as food and shelter. But man, in contrast to other living beings, has spiritual concerns - cognitive, aesthetic, social, political. Some of them are urgent, often extremely urgent, and each of them as well as the vital concerns can claim ultimacy for a human life or the life of a social group. If it claims ultimacy it demands the total surrender of him who accepts this claim, and it promises total fulfilment even if all other claims have to be subjected to it or rejected in its name.'

${ }^{23}$ See Madell (1996: 75). 
Thus, the feeling of religious longing is a state tending away from something and at the same time tending towards something else.

Fifth: Roberts and Madell do not just elaborate a theory of longing, but also specify the relation between the feeling of longing and other kinds of feelings: Roberts characterizes concerns as dispositions to a variety of emotions, and argues that having a concern of a specific kind is necessary for experiencing religious emotions. ${ }^{24}$ Madell distinguishes an internal and an external perspective on music: the internal perspective presupposes an interest in the development of the music; the external perspective lacks such an interest. Only emotions based on an internal perspective on music are genuine musical emotions. ${ }^{25}$ What qualifies emotions as musical is their reference to a musical interest, their dependency on the feeling of musical longing. Genuine musical emotions have to be distinguished from emotions which are elicited by music, but are based on an external perspective on it. An example of an emotion of this kind is boredom which is evoked by a piece of music, but does not represent a musical quality. At the same time, it is at least theoretically conceivable to feel genuine musical boredom, for example, if a piece of music always meets our musical expectations immediately. The classification of a phenomenon of boredom as an instance of musical boredom is not to be confused with classifying it as purely musical boredom, and therefore not real boredom. ${ }^{26}$ Rather, by labelling the feeling as a musical feeling we specify the particular domain to which the interest which is crucial for our emotion belongs.

Applying this to religious feelings entails that religious longing is a precondition of having religious emotions. These emotions represent whether and how our longing is fulfilled. If we take the plausibility of the analogy to musical feelings as a given, we can, furthermore, conclude that the dependency on religious longing (or another kind of religious concern) is what qualifies an emotion as religious.

The phenomenon of religious longing thus offers five challenges to a philosophical theory of feelings: firstly, the possibility of feelings that are not recognized as such by the person who feels them; secondly, the possibility of negative feelings which are at least partly experienced as pleasurable; thirdly the possibility of feelings which are not directed

\footnotetext{
24 See Roberts (2007: 12).

${ }^{25}$ See Madell (1996: 73).

${ }^{26}$ See Madell (1996: 81).
} 
towards individual objects, but towards our being in the world as a whole; fourthly, the possibility of feelings that partly represent our current state as being in a certain way, but at the same time involve a kind of striving pointing beyond this current state; and fifthly, the possibility of feelings being necessary conditions of other kinds of feelings.

But in virtue of what is religious longing itself classified as religious? It is classified as religious in virtue of what it is about, what it is directed at and how it is. Musical longing is an interest we may or may not take in the course of music. The same is true for being in love with a particular person. On the contrary, religious longing is not an interest we can have or lack. What our longing is about is the good life. Being concerned with the good life is part of what makes us what we are. Musical and sexual longing are kinds of longing which can be fulfilled within our finite world. We can specify the conditions under which our longing would be fulfilled and determine the extent to which these conditions are already met. Religious longing, in contrast, is a longing for something that transcends the sensual world. Its content is specified in a purely negative manner. There are no evidential criteria for the fulfilment of our longing. Musical and sexual longing are finite kinds of longing: we take an interest in the object of our longing, but if our longing remains unfulfilled, life still seems possible to us. In contrast, religious longing consists in being infinitely interested in passion. If it remains unfulfilled, it is not simply the case that a special interest of ours remains unsatisfied. What is at stake is not simply the meaning of life or explanation of the world, but the very possibility of meaning and explanation altogether. As I argued above, what we are longing for is characterized by partly being within and partly beyond our own power.

\section{THE TRANSITION FROM RELIGIOUS LONGING TO RELIGIOUS BELIEF}

What is the relation between the transition from religious longing to religious belief and (theories of) rationality?

First of all, it is important to note that the transition from religious longing to religious belief cannot be justified by reference to a cognitive theory of religious longing. 'Cognitive' is here to be understood in the broad sense. A cognitive state of mind has a representational content and therefore is subject to conditions of appropriateness, of correctness 
or even of truth. In his book 'Emotional Experience and Religious Understanding, Mark Wynn applies several theoretical approaches to the modern philosophy of emotion to the field of religion. He aims at vindicating what he calls a 'soft rationalism' of religious belief. ${ }^{27}$ Soft rationalism is a position which, according to Wynn, differs from 'fideism' by giving relevance to evidence and argument, and from 'hard rationalism' by taking into account the possibility that affective experiences might also bear cognitive significance. The 'personal, affectively toned experiences' Wynn focuses on in his defence of soft rationalism are emotions, and thus evaluative representational states of mind. One of the approaches Wynn tries to apply is Madell's theory of musical emotions. He introduces Madell as a representative of a theory of feeling which takes feelings to be 'themselves kinds of thought or understanding. ${ }^{28}$ This is surprising, as Wynn refers to a quote of Madell in which he explicitly classifies the feeling of religious longing as a desire:

hearing the dominant seventh evokes a desire, and sometimes something akin to a longing, for its resolution. That is a state of consciousness directed to an intentional object; it is also an affective state of consciousness. It is not an entertaining of an evaluation which (magically) leads to certain bodily disturbances. One may, if one is so disposed, regard the desire for the tonic resolution as ground for the evaluation that such a resolution would be 'a good thing', but it would be a total distortion to suppose that the desire, or the longing, is an evaluation, one which inexplicably leads to certain physical effects. It is a mode of 'feeling towards' its intentional object. $^{29}$

Madell here criticizes an add-on theory of longing which conceptualizes musical longing as an evaluation plus an affective reaction caused by this evaluation. But his alternative account does not consist in taking musical longing to be an affective state which represents something, but in taking it to be an affective state which tends towards something. ${ }^{30}$ It is misleading

${ }^{27}$ Wynn (2005: ix).

${ }^{28}$ Wynn (2005: 90).

${ }^{29}$ Madell (1996: 78). Cf. also p. 72: 'I have described our experience as the arousal of tension and a desire for relaxation, for its resolution on the tonic chord. What is evoked is a state of consciousness which is not merely one of affect, but which is also intentional: a desire, affective in itself, for a specific object.'

${ }^{30}$ Madell takes the concept of 'feeling towards' from a paper of D.W. Hamlyn's about 'The Phenomena of Love and Hate', published in 1978. It differs significantly from Goldie's concept of 'feeling towards'. Cf. Goldie (2000: 19). 
of him to refer to musical longing as well as to musical joy, triumph, disappointment and sadness as emotions. ${ }^{31}$ We should differentiate between the musical longing for harmonious resolution and emotions which have a representational content which is relative to the feeling of musical longing. According to Madell the musical emotions of joy and triumph mirror the fulfilment of our longing, whereas the emotions of disappointment and sadness mirror the lack of fulfilment. These emotions are felt only by someone who takes an internal perspective on music. This internal perspective is characterized by taking an interest in the development of the music and the harmonious resolution of musical tensions. Madell leaves it open whether this feeling of longing should itself be understood in cognitive terms.

Wynn claims that in the case of musical appreciation, feeling is able to take us beyond a certain sensory input so as to pick out a reality that has yet to be fully revealed in sensory terms; and analogously, in the case of God, feeling is able to take us beyond a certain doxastic input, so as to relate us to a reality that has yet to be fully understood in doxastic terms. ${ }^{32}$ But even if one concedes that religious longing is a cognitive state, it cannot justify religious beliefs - at least not those religious beliefs we are interested in: even if religious longing is appropriate in the sense that the current state is indeed painful and that what one longs for is indeed valuable, this does not justify the transition from religious longing to the religious belief that what one longs for is or will become real. Someone who anticipates the resolution of a dominant seventh chord into the tonic might be justified in perceiving the dominant seventh chord as a state of tension and in anticipating its resolution into the tonic as a harmonious and therefore valuable course for the music to take - but this does not justify his belief that such a resolution actually will take place. So what is misleading in Wynn's statement is his talk about 'reality'. In the state of longing we do not feel what is or will become real, but what should be or should become real. The dictum that the heart, which tends towards something, sometimes leads us better than reason, which represents something, is at the same time provocative and interesting for exactly the reason that feeling is not just another representational faculty.

But why exactly is the transition from religious longing to religious belief provocative? It is provocative because it is an instance of wishful

${ }^{31}$ Cf. Madell (1996: 73).

32 Wynn (2005: 146). 
thinking. Wishful thinking consists in believing a fact to be true because one desires it to be true. The transition from religious longing to religious faith is an act which we are responsible for, not a mere event that happens to us. However, it seems to be questionable whether it is at all conceptually possible - and if so, whether it is psychologically possible to believe something because one wishes it to be true. According to common opinion, believing is a receptive capacity which we can at most influence indirectly. At this point a conceptual specification of the concept of religious belief will be helpful: religious belief consists in taking a proposition to be true, not in holding it to be true. ${ }^{33}$ Holding a proposition to be true is a mental state; taking a proposition to be true is a mental act which consists in taking a proposition as a true premise in one's (practical) reasoning. Thus, the basic provocation of religious belief more precisely consists in the decision to take to be true a proposition which one desires to be true, though one knows that one is not justified in doing so by one's total available evidence. ${ }^{34}$ If one assumes that taking a proposition to be true comes in degrees, the believer fully commits himself to take the proposition to be true. He wholeheartedly chooses to live under the idea of God or the Divine.

While it seems to be questionable whether we can ever be pragmatically justified in holding a proposition to be true, pragmatic justifications for taking something to be true seem to be less problematic. Therefore, at first sight it seems to be possible that the decision to take to be true what one longs to be true should be pragmatically justified. Pragmatic justifications are justifications for taking (or holding) something to be true, rather than for taking (or holding) something to be true. ${ }^{35}$ They rely on a value which is either inherent in the attitude itself or is realized by it (or is likely to be). Tolstoy states that his decision to live under the idea of God despite his knowledge that he is not epistemically justified in so doing brings the gruelling fluctuation between confidence and desperation to an end.

${ }^{33}$ For this distinction cf. Bishop (2007: 33-35).

${ }^{34}$ Bishop argues from the perspective of a 'reflective believer' who questions the admissibility of his religious beliefs. He vindicates the stronger claim that under certain circumstances it is admissible to take and hold a proposition to be true though one knows that its truth is not supported by one's total available evidence. Cf. Bishop (2007: 5f.).

${ }^{35}$ The distinctions between taking and holding something to be true and between epistemic and pragmatic justifications are two different distinctions: taking and holding something to be true are attitudes towards propositions; epistemic and pragmatic justification deal with the legitimacy of having a certain attitude of belief towards a proposition. 
He feels better because he believes in God. The pragmatic justification may also depend on the truth of what one believes. This for example is the case if the 'reward' is handed out by God himself or allotted only after death. Pascal famously argues that we should believe in God because the infinite reward we will gain if God exists outweighs the possible losses and gains of any other option we have.

Tolstoy's and Pascal's arguments are contestable. It is, for example, contentious whether Pascal's premises are valid and whether Tolstoy's decision ultimately ends his longing and suffering. As I have argued, the feeling of religious longing continues in the state of faith in a modified form. One can question whether pragmatic considerations can in the case in question - or indeed, ever - justify one in taking something to be true despite the lack of sufficient evidence. But the crucial point is another: the phenomenon we are dealing with, the transition from religious longing to religious belief, is not motivated by pragmatic considerations of the kind described. One does not decide to believe because oneself, or someone or something else, will be better off if one does so. Tolstoy says, 'I need only be aware of God to live; I need only forget Him, or disbelieve Him, and I died.' Tolstoy's interest expressed in the feeling of religious longing is existential, or, as James says, 'momentous. ${ }^{36}$ Tolstoy decides to believe because otherwise life does not seem possible to him. Thus, the choice does not present itself as a choice between a better and a worse outcome, but as a choice between the possibility and the impossibility of life. Above, I referred to specifications of the phenomenon of religious longing which interpret it as a longing for both meaning and understanding. Assuming that this is so, we can specify that what is at stake in the choice is the meaningfulness and understandability of life as such, that is the possibility of meaning and understanding.

The argument now resembles a transcendental, rather than a pragmatic argument. What is at stake is not the realisation of a value, but the condition of possibility of a value. Transcendental arguments take a phenomenon as a given and identify the conditions which have to be met for that phenomenon to be possible. In the case at hand, the transcendent reality appears to be a condition of the possibility for life, meaning and understanding. We decide to live under the idea of God or the Divine, because otherwise no good life seems possible to us. Ordinary transcendental arguments are considerations of 'pure reason'.

${ }^{36}$ James (1896: 329). 
In contrast, the transition from religious longing to religious belief is a passionate movement: in the feeling of religious longing one experiences that no life is possible in the finite world. This experience motivates the decision to believe in a transcendent reality. This decision itself is performed passionately. One wholeheartedly commits oneself to belief in the transcendent reality. One earnestly takes it to be true in all areas of life with the maximum degree of confidence.

This distinguishes faith-commitments from other cases in which something is taken to be true without sufficient evidence, which include the hypothetical attitude of a scientist, the experimental attitude of a modern lifestylist, and the ironic attitude of a postmodern aesthete. Though the scientist may be highly interested in the truth of his hypothesis, his interest is not usually existential. His academic career and the life of other people may be at stake, but not the possibility of life as such. Furthermore, he does not commit himself to the truth of his hypothesis wholeheartedly. The relevancy of his hypothesis may be restricted to a certain area; he may take it to be true with less than full commitment and he may do so without being emotionally involved at all. In contrast to scientific hypotheses, religious belief is - by its very nature - incapable of empirical falsification, because the object of religious longing is transcendent. ${ }^{37}$ Someone who tries out different lifestyles in an experimental manner lacks the infinite interest of feeling as well as the decisiveness of decision which characterize the transition from religious longing to religious belief. The modern lifestylist may well be motivated by pragmatic considerations. He chooses the religion which makes him feel best. If the expected result does not take place he turns to another religion. Likewise, postmodern aesthetes maintain the gap between who they are and what they take to be true. Carrying out the leap of faith on the basis of a feeling of religious longing is to abolish this gap.

We can conclude that the transition from religious longing to religious belief is neither epistemically justified by the representational content of the feeling of longing nor pragmatically justified by some kind of value which is realised by taking to be true what one longs for (given that one wants to adhere to an internalist theory of justification). Rather, one decides to wholeheartedly take as true what one experiences in the feeling of longing as a condition of the possibility of (an understandable,

${ }^{37}$ Cf. James (1896: 334); Bishop (2007: chapter 4). 
meaningful) life. The transition from religious longing to religious belief is characterized by its object (the transcendent), its motive (existential interest) and its mode (earnestness). The feeling of religious longing fulfils the role of rationalizing our practical commitment to a belief which by its nature cannot be justified on the basis of evidence. The concept of passionate rationality captures the idea that under certain restricted conditions we are justified in taking as true what we passionately long to be true. ${ }^{38}$

\section{CONCLUSION}

Religious longing as a motivation for religious faith opens up an interesting perspective on theories of feelings, theories of religious feelings and theories of rationality. Following Roberts, we can classify religious longing as a passion. We experience our current being as a state of tension by which we are repulsed, and at the same time we anticipate the possible resolution of this tension to which we are attracted. Religious longing is characterized by (1) its generality, (2) its indeterminate transcendent object which by its nature is not capable of empirical verification or falsification, (3) its mode of being infinitely interested in passion and (4) its ambiguity with regard to our own power and powerlessness. Theories of feeling have to account for these kinds of passionate feelings. The passionate feeling of religious longing and the religious belief motivated by this feeling furthermore enables other kinds of religious feelings. If we conceive of the transition from religious longing to religious belief as a paradigmatic instance of 'passionate rationality' we have a starting point for rethinking the relation between feelings and rationality. As emotions, they epistemically justify beliefs by means of their representational content. As feelings, they pragmatically justify beliefs by means of their hedonic character. As passions, they passionately justify commitments to the truth of something by means of expressing an existential interest.

${ }^{38}$ These conditions of course need further specification and discussion which cannot be given in this article. Especially, it is of great importance to account for possible moral restrictions. See Bishop (2007). 


\section{BIBLIOGRAPHY}

Bishop, John. 2007. Believing by Faith: An Essay in the Epistemology and Ethics of Religious Belief (Oxford: Oxford University Press)

Goldie, Peter. 2000. The Emotions: A Philosophical Exploration (Oxford: Oxford University Press)

Habermas, Jürgen. 2001. Glauben und Wissen: Friedenspreis des Deutschen Buchhandels 2001 (Frankfurt am Main: Suhrkamp)

James, William. 1896. 'The Will to Believe', in The New World: A Quarterly Review of Religion, Ethics and Theology, V, 327-347

James, William. 2002. The Varieties of Religious Experience (Mineola, New York: Dover Publications)

Kant, Immanuel. 1998. Kritik der reinen Vernunft (Hamburg: Felix Meiner Verlag (Philosophische Bibliothek))

Kierkegaard, Søren. 1980. The Sickness Unto Death: A Christian Psychological Exposition for Upbuilding and Awakening, ed. and transl. by Howard V. Hong and Edna H. Hong (Princeton, NJ: Princeton University Press (Kierkegaard's Writings, Vol. 19))

Kierkegaard, Søren. 1987. Either/Or. Part I, ed. and transl. by Howard V. Hong and Edna H. Hong (Princeton, NJ: Princeton University Press (Kierkegaard's Writings, Vol. 3))

Madell, Geoffrey. 1996. 'What Music Teaches about Emotion', in Philosophy, 71 (275), 63-82

New American Standard Bible (Anaheim, California: Foundation Publications, 1995)

Roberts, Robert C. 2003. Emotions: An Essay in Aid of Moral Psychology (Cambridge: Cambridge University Press)

Roberts, Robert C. 2007. Spiritual Emotions: A Psychology of Christian Virtues (Grand Rapids, Mich.: William B. Eerdmans Publishing)

Schelling, Friedrich Wilhelm Joseph. 2001. Philosophische Untersuchungen über das Wesen der menschlichen Freiheit und die damit zusammenhängenden Gegenstände (Hamburg: Meiner)

Schleiermacher, Friedrich. 2001. Über die Religion: Reden an die Gebildeten unter ihren Verächtern (Berlin: de Gruyter)

Theunissen, Michael. 1981. 'Kierkegaard's Negativistic Method', in Kierkegaard's Truth: The Disclosure of the Self, ed. by Joseph H. Smith (New Haven: Yale University Press (Psychiatry and the Humanities, Vol. 5)), 381-423

Tolstoy, Leo. 1940. A Confession, The Gospel in Brief and What I Believe, trans. by Aylmer Maude (London: Oxford University Press)

Weber, Max. 1994. Briefe 1909-1910 (Tübingen: J. C. B. Mohr (Gesamtausgabe, Abt. 2, Bd. 6))

Wynn, Mark. 2005. Emotional Experience and Religious Understanding: Integrating Perception, Conception and Feeling (Cambridge: Cambridge University Press) 